A C G

publications records of agricultural and food chemistry

\title{
Allelopathic Effect of Aqueous Extracts of Stinkwort \\ (Dittrichia graveolens L.) on Germination and Growth of Some
}

Weed Species

\section{Kamal Almhemed ${ }^{1}$, Muhammad Al Sakran ${ }^{1}{ }^{1}$, Tamer Üstüner ${ }^{1}{ }^{1}$ and Menderes Ustüner ${ }^{\odot}$ 2*}

\author{
${ }^{I}$ Department Plant Protection, Faculty of Agriculture, Kahramanmaras Sutcu Imam University- \\ Türkiye \\ ${ }^{2}$ Vocational School of Cag University, Cag university-Türkiye
}

(Received July 28, 2021; Revised, August 18, 2021; Accepted September 6, 2021)

\begin{abstract}
The experiment was implemented by CRD design with three replications and lasted for 40 days, from 5 October until 15 November 2020. Four extract concentrations of D. graveolens $0,2,6$, and 10\% were used. The concentration of $0 \%$ was considered as control. The allelopathic effect has been studied on five weed species; Amaranthus retroflexus L., Portulaca oleracea L., Lolium multiflorum Lam., Sorghum halepense L., and Cuscuta campestris Yunck. The research also aimed to determine the effect of Stinkwort extract on the growth of tomato seedlings. All concentrations affected seed germination for all studied weeds. The concentration of $10 \%$ was more influential in growth-related indicators compared to other concentrations. The seeds of L. multiflorum and rhizomes of $S$. halepense were more tolerant to $D$. graveolens allelochemicals in germination rate than $A$. retroflexus, $P$. oleracea, and $C$. campestris. All concentrations led to a reduction in the weed heights and the wet and dry weights compared with the controls. The effect of the extract with various concentrations was catalytic for the growth of tomato seedlings, as the average height of tomato seedlings was in direct proportion to the concentration.
\end{abstract}

Keywords: Allelochemicals; weeds, seeds; rhizomes; concentration. (C) 2021 ACG Publications. All rights reserved.

\section{Introduction}

There are about 250.000 flowering plant species scattered throughout the world; approximately $3.2 \%$ of them are listed as weeds, the most notable losses in crop yields caused by 250 species of these weeds [1]. The weeds are widely distributed in crop fields, as their density varies according to the climatic conditions in each region. For example, 121 weed species belonging to 31 families have been identified spread in Chickpeas fields in Kahramanmaras [2] and Diyarbakir cities located in Turkey, 72 weed species belonging to 21 families were found in Barley fields [3]. Overall, weeds cause significant losses in crop yield more than other pests [4]. The losses in crop yields caused by weeds depend on

\footnotetext{
* Corresponding author: E-Mail: mustuner@cag.edu.tr 


\section{Allelopathic effect of aqueous extracts Dittrichia graveolens L}

various factors such as crop type, weed species, and density [5]. In Iraq, according to some studies, the weeds can cause losses in Wheat yield ranging from 13 to 43\% [6]. In India, the total losses caused by weeds in 10 major crops were estimated at 11 billion dollars between 2003 and 2014 [7]. In North America, the yield loss of dry beans in 2016 reached $71.4 \%$ due to uncontrolled weeds [8]. One field study reported that $C$. campestris might cause a loss in crop yields ranging from 26 to $100 \%$ depending on crop types and severity of infection [9]. In Turkey, a study was conducted to estimate the losses caused by $C$. campestris in the sugar beet yield. The study results showed that the loss in the crop yield reached 22 tons per hectare [10]. It was reported that $C$. campestris caused yield losses in Cassava crops estimated at $48 \%$ per plant [11]. One study reported that $A$. retoflexus reduced crop yield significantly, where the losses reached $50 \%$ in Soy fields and $45 \%$ in Cornfields [12]. In a study conducted to determine the effect of competition between A. retroflexus and Cotton crop, it was found that the spread of $A$. retroflexus with $0.20-0.33 / \mathrm{m} 2$ density led to a loss of $50 \%$ of cotton seed yields [13]. It was reported that the spread of one Lolium species in wheat at $200 / \mathrm{m} 2$ density caused a loss in the yield between 20 and 50\% [14]. Similarly reported that $S$. halepense might cause yield losses in agricultural crops about $88 \%$ if not controlled [15]. On the other hand, some researchers reported that $S$. halepense might cause a loss in cotton yield up to $54 \%$ if not controlled [16]. The herbicides that are used to control weeds have adverse effects on ecosystems [17]. In Iraq, the application of ineffective weed control programs has significantly decreased the cotton yield [18]. The soil can contain massive numbers of weed seeds [19]. One of the effective weed control methods is reducing the soil's reserve of weed seeds. Allelopathy means that is plant may produce allelochemicals, which affect stimulating or inhibition of other plants growth [20]. The competition between the weeds and crops is either directly through competition for essential elements needed for growth or indirectly through the allelopathic effects [21]. One study reported that using the combination of sunflower residues with half the dose of Chevalier 15 WG herbicide reduced weed density in wheat fields [22]. Weeds can be controlled through allelochemicals resulting from crop residues or other weeds in the field [23]. In a study conducted in Turkey, it was found that volatile oil extracted from Eucalyptus camaldulensis had an allelopathic inhibitory effect on the growth of some weeds, such as Melilotus officinalis L. and A. retroflexus L. [24]. In a study conducted to test the effect of aqueous extracts of $D$. graveolens on the germination of Wheat (Triticum aestivum L.) and Common ragweed (Ambrosia artemisiifolia L.) seeds, it was found that these extracts significantly reduced the germination of those seeds [25]. On the other hand, it was reported that the D. graveolens extracts could be used as biocides in organic farming systems [26]. This study aimed to investigate allelopathic effects of $D$. graveolens extract on germination and growth of some weed species such as $A$. retroflexus, $P$. oleracea, L. multiflorum, $S$. halepense, and $C$. campestris. Also aimed to determine the effect of Stinkwort extract on the growth of tomato seedlings.

\section{Materials and Methods}

\subsection{Plant Materials}

The samples (roots, stems, leaves, and flowers) of D. graveolens were collected during the flowering period in September 2020. Also, the weed seeds of A. retroflexus, P. oleracea, L. multiflorum, $S$. halepense, and C. campestris used in the experiment were collected from Agriculture Faculty lands, Kahramanmaras Sutcu Imam University, Turkey. Weeds seeds have been used at the age of one year for their high germination capacity [27]. Also, tomato seedlings Gulizar variety were obtained from the local market of Kahramanmaras.

\subsection{Preparation of Aqueous Extract}

The samples were air-dried at dark under room temperature in the laboratories of Kahramanmaras Sutcu Imam University, Agriculture Faculty, Department of Plant Protection. The dry samples of D. graveolens were ground to a powder by a mill (Retsch SK 100), the powdered plant material was mixed with the distilled water for $24 \mathrm{~h}$ at room temperature. After that, the extract was filtered and prepared in 4 concentrators $0,2,6$, and $10 \%$, where the concentration of $0 \%$ was considered 
as control. Concentrations were prepared by soaking $100 \mathrm{~g}$ of Stinkwort plant powder in 1 liter of water to obtain a $10 \%$ concentration. Then the extracts was placed in the refrigerator at $4{ }^{\circ} \mathrm{C}$ until use.

\subsection{Soil Preparation, Cultivation, and Bioassay Tests}

The experiment was conducted in the greenhouse of the Agriculture Faculty, Kahramanmaras Sutcu Imam University, Turkey. The experiment lasted for 40 days, from 5 Oct until 15 Nov 2020. The soil was prepared for cultivation by mixing soil, sand, and peat moss in the ratio of $1: 1: 1$. The tomato seedlings of the Gulizar variety, weed seeds, and rhizomes were cultivated in pots with $22 \mathrm{~cm}$ height and $21 \mathrm{~cm}$ top diameter. Before cultivation, the pots were sterilized formaldehyde $37 \%$ [28]. In each replication (pot), one tomato seedlings and 20 weed seeds were cultivated, as for the rhizomes of $S$. halepense, 10 rhizome nodes were cultivated in each pot. During the experiment period, the maximum and minimum temperatures were $31 \mathrm{C}^{\circ}$ and $12 \mathrm{C}^{\circ}$, respectively, and the humidity was $70 \%$. The height of tomato seedlings was calculated at the beginning of the experiment and after 40 days. The germination percentage of weed seeds was calculated using the following formula: Germination $\%=$ Number of germinated seeds / Total number of seeds $\times 100$ [29]. On the other hand, the height, wet and dry weights of weeds were calculated as well.

\subsection{Experiment Design and Data Analysis}

The experiment was conducted by Completely Random Design (CRD) with three replications. The data were analyzed and subjected to ANOVA and Least Significant Difference (LSD) at 0.05 probability level using the MSTATC program.

\section{Results and Discussion}

This study set out to investigate the allelopathic effects of aqueous extract of $D$. graveolens on germination and growth of A. retroflexus, $P$. oleracea, L. multiflorum, S. halepense, and C. campestris, as well as on height of tomato seedlings, where the results were as follows:

\subsection{Allelopathic Effect of Aqueous Extract of D. graveolens on A. retroflexus}

As shown in Table 1, the percentage of seed germination, plant height, and wet and dry weight in A. retroflexus were affected by the aqueous extract of $D$. graveolens. The effect of plant extract on seed germination was statistically similar to its effect on wet and dry weight at 6 and $10 \%$ concentrations, except for plant height, where the concentration of $10 \%$ reduced the plant height significantly compared to other treatments. General increasing the concentration of the aqueous extract of allelopathic plants leads to an increase in growth inhibition [28].

\subsection{Allelopathic Effect of Aqueous Extract of D. graveolens on P. oleracea}

The growth-related indicators (seed germination percentage and the wet and dry weight) of $P$. oleracea were affected significantly by all treatments compared with the control. As shown in Table 2, there were no significant differences between the three concentrations $(2,6$, and $10 \%)$. The results of data analysis showed that the concentration of $10 \%$ surpassed other treatments (2 and 6\%) and significantly surpassed the control in reducing plant height. Ethanolic extract of $D$. graveolens reduced root length, of $P$. oleracea seedlings in which the root length was inhibited by $99 \%$ compared with other affected plant species [30]. 
Allelopathic effect of aqueous extracts Dittrichia graveolens L

Table 1. Allelopathic effect of aqueous extract of D. graveolens on germination and growth of $A$. retroflexus.

\begin{tabular}{ccccc}
\hline Concentrations & $\begin{array}{c}\text { Seed's } \\
\text { germination \% }\end{array}$ & $\begin{array}{c}\text { A. retroflexus plant } \\
\text { height/cm }\end{array}$ & $\begin{array}{c}\text { A. retroflexus } \\
\text { wet weight/g }\end{array}$ & $\begin{array}{c}\text { A. retroflexus } \\
\text { dry weight/g }\end{array}$ \\
\hline $10 \%$ & $15.00^{\mathrm{a}}$ & $7.63^{\mathrm{a}}$ & $3.94^{\mathrm{a}}$ & $0.77^{\mathrm{a}}$ \\
$6 \%$ & $23.33^{\mathrm{ab}}$ & $14.60^{\mathrm{b}}$ & $4.60^{\mathrm{a}}$ & $0.94^{\mathrm{a}}$ \\
$2 \%$ & $21.67^{\mathrm{ab}}$ & $18.47^{\mathrm{c}}$ & $6.89^{\mathrm{b}}$ & $1.40^{\mathrm{b}}$ \\
$0 \%$ & $28.33^{\mathrm{b}}$ & $19.03^{\mathrm{c}}$ & $9.90^{\mathrm{c}}$ & $1.98^{\mathrm{c}}$ \\
\hline LSD & $\mathbf{9 . 4 1 8}$ & $\mathbf{1 . 6 5 5}$ & $\mathbf{1 . 9 3 6}$ & $\mathbf{0 . 3 7 3 8}$ \\
\hline
\end{tabular}

Values followed by the same letter (s) in the same column are not significantly different from each other at 0.05 level of probability.

Table 2. Allelopathic effect of aqueous extract of $D$. graveolens on germination and growth of $P$. oleracea

\begin{tabular}{ccccc}
\hline Concentrations & $\begin{array}{c}\text { Seed's } \\
\text { germination } \%\end{array}$ & $\begin{array}{c}\text { P. oleracea } \text { plant } \\
\text { height/cm }\end{array}$ & $\begin{array}{c}\text { P. oleracea wet } \\
\text { weight/g }\end{array}$ & $\begin{array}{c}\text { P. oleracea dry } \\
\text { weight/g }\end{array}$ \\
\hline $10 \%$ & $1.33 \mathrm{a}$ & $7.23 \mathrm{a}$ & $3.46 \mathrm{a}$ & $0.47 \mathrm{a}$ \\
$6 \%$ & $5.00 \mathrm{a}$ & $8.40 \mathrm{ab}$ & $3.80 \mathrm{a}$ & $0.55 \mathrm{a}$ \\
$2 \%$ & $6.67 \mathrm{a}$ & $8.73 \mathrm{bc}$ & $5.71 \mathrm{a}$ & $0.71 \mathrm{a}$ \\
$0 \%$ & $21.67 \mathrm{~b}$ & $9.87 \mathrm{c}$ & $11.09 \mathrm{~b}$ & $1.73 \mathrm{~b}$ \\
\hline LSD & $\mathbf{5 . 4 0}$ & $\mathbf{1 . 1 7 0}$ & $\mathbf{3 . 4 7 0}$ & $\mathbf{0 . 4 2 8 5}$ \\
\hline
\end{tabular}

Values followed by the same letter (s) in the same column are not significantly different from each other at 0.05 level of probability

\subsection{Allelopathic Effect of Aqueous Extract of D. graveolens on L. multiflorum.}

According to Table 3 , the seed germination percentage was not significantly affected by the concentrations of 2 and $6 \%$ compared to control. As well as the concentration of $10 \%$ surpassed the other treatments significantly, where it recorded the less seed germination rate reached $33.33 \%$. The effect of $D$. graveolens extract on plant height was statistically similar to its effect on dry and wet weight at concentrations of 6 and 10\%. Low concentrations may not have obvious effects on plant growth suppression. There was no effect of aqueous extracts at $4 \%$ concentration of $D$. graveolens on germination index and growth of Lactuca sativa L., Raphanus sativus L., Peganum harmala L. and Silybum marianum L. [31]. 
Almhemed et.al., Rec. Agric. Food. Chem. (2021) 1:1-2 3-11

Table 3. Allelopathic effect of aqueous extract of $D$. graveolens on germination and growth of $L$. multiflorum.

\begin{tabular}{ccccc}
\hline Concentrations & $\begin{array}{c}\text { Seed's } \\
\text { germination\% }\end{array}$ & $\begin{array}{c}\text { L. multiflorum plant } \\
\text { height/cm }\end{array}$ & $\begin{array}{c}\text { L. multiflorum } \\
\text { wet weight/g }\end{array}$ & $\begin{array}{c}\text { L. multiflorum } \\
\text { dry weight/g }\end{array}$ \\
\hline $10 \%$ & $33.33 \mathrm{a}$ & $26.60 \mathrm{a}$ & $4.56 \mathrm{a}$ & $1.37 \mathrm{a}$ \\
$6 \%$ & $46.63 \mathrm{bc}$ & $29.50 \mathrm{ab}$ & $5.84 \mathrm{a}$ & $1.75 \mathrm{a}$ \\
$2 \%$ & $46.67 \mathrm{bc}$ & $31.30 \mathrm{~b}$ & $8.61 \mathrm{~b}$ & $2.58 \mathrm{~b}$ \\
$0 \%$ & $68.33 \mathrm{c}$ & $35.60 \mathrm{c}$ & $11.49 \mathrm{c}$ & $3.83 \mathrm{c}$ \\
\hline LSD & $\mathbf{2 4 . 6 9}$ & $\mathbf{3 . 3 0 7}$ & $\mathbf{1 . 9 8 4}$ & $\mathbf{0 . 6 3 8 1}$ \\
\hline
\end{tabular}

Values followed by the same letter (s) in the same column are not significantly different from each other at 0.05 level of probability.

\subsection{Allelopathic Effect of Aqueous Extract of D. graveolens on S. halepense}

\subsubsection{S. halepense (rhizomes)}

As shown in Table 4 , the concentration of $10 \%$ significantly surpassed the control in reducing the percentage of rhizomes germination, which recorded $46.67 \%$. On the other hand, the concentration of $10 \%$ reduced the $S$. halepense height significantly more than other treatments where it recorded 12.60 $\mathrm{cm}$. The wet and dry weight of $S$. halepense were not affected by any of the applied concentrations, and there were no significant differences between those treatments and the control.

Table 4. Allelopathic effect of aqueous extract of $D$. graveolens on germination and growth of $S$. halepense (rhizomes)

\begin{tabular}{ccccc}
\hline Concentrations & $\begin{array}{c}\text { Rhizome's } \\
\text { germination } \%\end{array}$ & $\begin{array}{c}\text { S. halepense } \text { plant } \\
\text { height/cm }\end{array}$ & $\begin{array}{c}\text { S. halepense wet } \\
\text { weight/g }\end{array}$ & $\begin{array}{c}\text { S. halepense } \\
\text { dry weight/g }\end{array}$ \\
\hline $10 \%$ & $46.67 \mathrm{a}$ & $12.60 \mathrm{a}$ & $2.27 \mathrm{a}$ & $1.06 \mathrm{a}$ \\
$6 \%$ & $60.03 \mathrm{ab}$ & $14.40 \mathrm{~b}$ & $3.27 \mathrm{a}$ & $0.45 \mathrm{a}$ \\
$2 \%$ & $66.67 \mathrm{ab}$ & $15.63 \mathrm{~b}$ & $5.56 \mathrm{a}$ & $0.46 \mathrm{a}$ \\
$0 \%$ & $76.67 \mathrm{~b}$ & $15.93 \mathrm{~b}$ & $8.28 \mathrm{a}$ & $1.67 \mathrm{a}$ \\
\hline $\mathbf{L S D}$ & $\mathbf{2 5 . 7 9}$ & $\mathbf{1 . 6 0 3}$ & $\mathbf{7 . 4 0 3}$ & $\mathbf{1 . 3 7 8}$ \\
\hline $\begin{array}{l}\text { Values followed by the same letter (s) in the same column are not significantly different from each other at } 0.05 \text { level of } \\
\text { probability. }\end{array}$
\end{tabular}


Allelopathic effect of aqueous extracts Dittrichia graveolens L

\subsubsection{S. halepense (seeds)}

The three treatments of 2,6, and $10 \%$ affected the percentage of seed germination, plant height, and wet and dry weights for $S$. halepense. All treatments reduced those indicators significantly compared to the control. On another side, as is evident in Table 5, the only treatment that reduced S. halepense height was the concentration of $10 \%$, which recorded $8.27 \mathrm{~cm}$. The effect of allelochemicals on germination may be greater than on the growth and development of the target plant [28].

Table 5. Allelopathic effect of aqueous extract of D. graveolens on germination and growth of $S$. halepense (seeds).

\begin{tabular}{ccccc}
\hline Concentrations & $\begin{array}{c}\text { Seed's } \\
\text { germination } \%\end{array}$ & $\begin{array}{c}\text { S. halepense plant } \\
\text { height/cm }\end{array}$ & $\begin{array}{c}\text { S. halepense wet } \\
\text { weight/g }\end{array}$ & $\begin{array}{c}\text { S. halepense } \\
\text { dry weight/g }\end{array}$ \\
\hline $10 \%$ & $18.33 \mathrm{a}$ & $8.27 \mathrm{a}$ & $0.09 \mathrm{a}$ & $0.03 \mathrm{a}$ \\
$6 \%$ & $20.00 \mathrm{a}$ & $10.53 \mathrm{~b}$ & $0.16 \mathrm{a}$ & $0.04 \mathrm{a}$ \\
$2 \%$ & $21.67 \mathrm{a}$ & $10.70 \mathrm{~b}$ & $0.18 \mathrm{a}$ & $0.05 \mathrm{a}$ \\
$0 \%$ & $31.67 \mathrm{~b}$ & $11.57 \mathrm{~b}$ & $5.88 \mathrm{~b}$ & $1.46 \mathrm{~b}$ \\
\hline LSD & $\mathbf{8 . 9 6 6}$ & $\mathbf{1 . 0 6 7}$ & $\mathbf{0 . 1 5 4 8}$ & $\mathbf{0 . 0 6 3 1 8}$ \\
\hline
\end{tabular}

Values followed by the same letter (s) in the same column are not significantly different from each other at 0.05 level of probability

\subsection{Allelopathic Effect of Aqueous Extract of D. graveolens on C. campestris}

According to Table 6, all the treatments led to a decrease in seed germination percentage and the wet and dry weights of $C$. campestris. The seed germination percentage was $8.33 \%$ in the treatment of $10 \%$, while it reached $35 \%$ for the control. There were no significant differences between the three concentrations $(2,6$, and $10 \%)$, and all of them surpassed the control in reducing the studied growthrelated indicators.

Table 6. Allelopathic effect of aqueous extract of $D$. graveolens on germination and growth of $C$. campestris

\begin{tabular}{cccc}
\hline Concentrations & Seed's germination \% & C. campestris wet weight/g & $\begin{array}{c}\text { C. campestris dry } \\
\text { weight } / \mathbf{g}\end{array}$ \\
\hline $10 \%$ & $8.33 \mathrm{a}$ & $4.83 \mathrm{a}$ & $1.13 \mathrm{a}$ \\
$6 \%$ & $11.67 \mathrm{a}$ & $6.77 \mathrm{a}$ & $1.59 \mathrm{a}$ \\
$2 \%$ & $13.33 \mathrm{a}$ & $7.73 \mathrm{a}$ & $1.81 \mathrm{a}$ \\
$0 \%$ & $35.00 \mathrm{~b}$ & $20.30 \mathrm{~b}$ & $4.76 \mathrm{~b}$ \\
\hline LSD & $\mathbf{7 . 4 4 6}$ & $\mathbf{4 . 3 1 8}$ & $\mathbf{1 . 0 1 3}$
\end{tabular}

Values followed by the same letter (s) in the same column are not significantly different from each other at 0.05 level of probability. 


\subsection{Allelopathic Effect of Aqueous Extract of D. Graveolens on the Height of Tomato Seedlings}

As Figure 1 shows, the various treatments played a catalytic role for the growth of tomato seedlings, as the average height of tomato seedlings in direct proportion to the concentration, recording $20.83,22.10,23.74$, and $27.07 \mathrm{~cm}$ for treatments of $0,2,6$ and $10 \%$, respectively. The effect of aqueous extract of $D$. graveolens on growth tomato seedlings confirms that the allelopathic effect can be positive and encourage plant growth. [32].

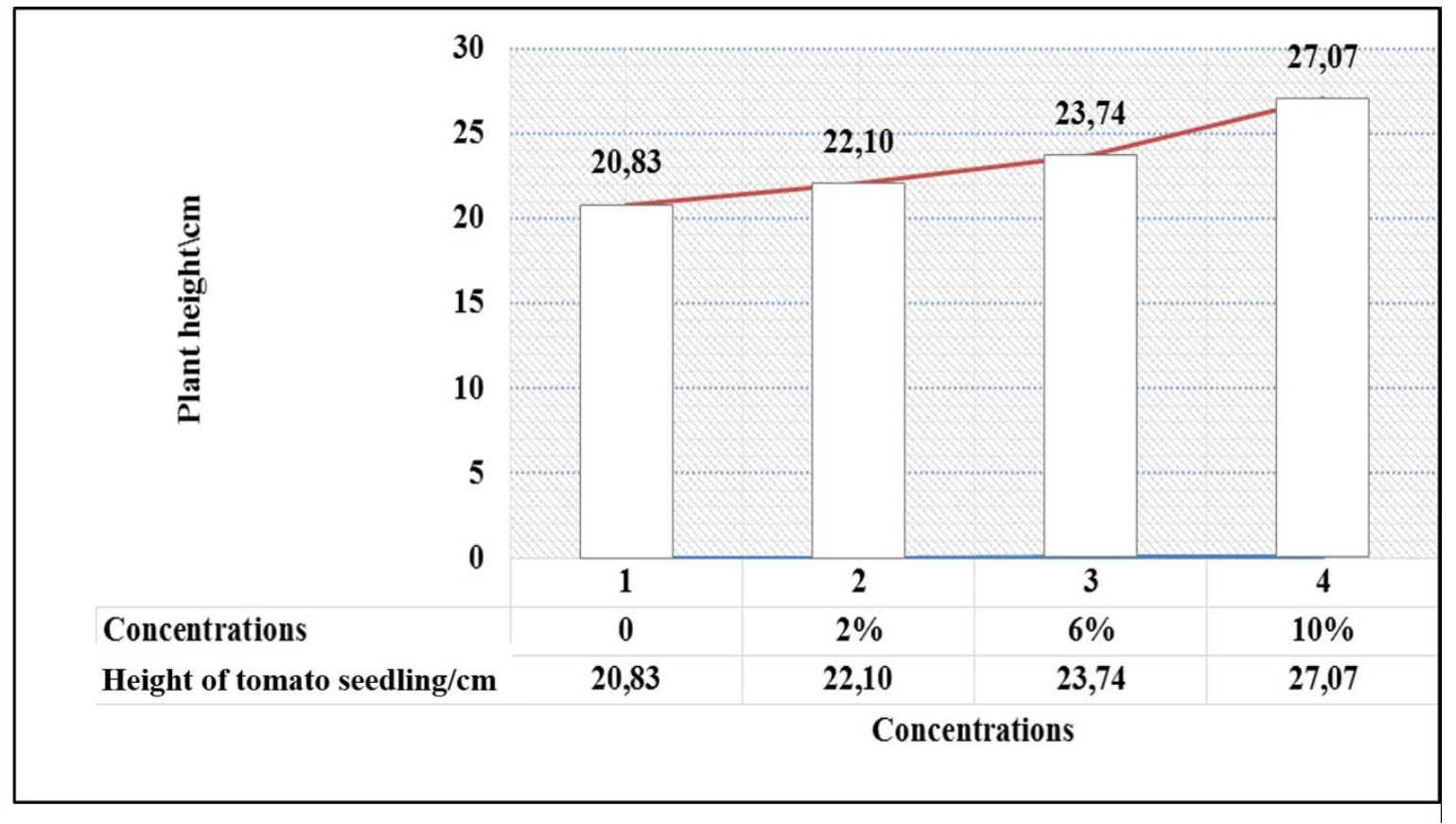

Figure 1. Allelopathic effect of aqueous extracts of $D$. graveolens on the height of tomato seedlings

\section{Conclusions}

The effect of aqueous extracts of D. graveolens at different concentrations on germination and growth varied according to the species, and the effect on germination was greater than on growth. The effect on the rhizome of $S$. halepense was less than on the seeds. The stimulating effect of the extracts was observed for tomato seedlings and this stimulation increased with increasing concentration. Perhaps the reason is the use of seedlings instead of seeds. Overall, using an aqueous extract of stinkwort $(D$. graveolens) at various concentrations $(2,6$, and $10 \%)$ can inhibit germination and growth-related indicators of $A$. retroflexus, P. oleracea, L. multiflorum, and C. campestris. It also can inhibit the seed germination and growth of $S$. halepense but did not affect the $S$. halepense seedlings arising from rhizomes. So, it can be used to reduce these weeds population in crop fields. It is clear from this study that the effect of the aqueous extracts of $D$. graveolens had a greater effect on the seeds than on the other parts of plant.

\section{Acknowledgments}

This work was supported by the Department of Plant protection at the Faculty of Agriculture, Kahramanmaras Sutcu Imam University-Turkey.

\section{ORCID}

Kamal Almhemed: 0000-0002-6061-689X 
Allelopathic effect of aqueous extracts Dittrichia graveolens L

Muhammad Al sakran: 0000-0001-6672-7016

Tamer Ustuner: 0000-0003-3584-4249

Menderes Ustüner: 0000-0003-4403-6230

\section{References}

[1] R. P. Borris (1996). Natural products research: perspectives from a major pharmaceutical company, J. Ethnopharmacol. 51, 29-38.

[2] T. Üstüner (2016). Determination of weed density, frequency, and general coverage areas in chickpea fields in Kahramanmaras, Turk. J. Weed. Sci. 19(2), 38-48.

[3] F. Pala (2020). Observation of weed species, frequency and density in Common barley (Hordeum vulgare L.) fields of Diyarbakir, Turkey: A case study, J. Agric. Sci. 26, 164-172.

[4] E. C. Oerke (2006). Crop losses to pests, J. Agric. Sci. 144, 31-43.

[5] J. Abdul Shukor, M. d. Kamal, M. d. Parvez, A. Mahmud Tengku, M. Razi and M. Azmi (2013). Sustainable weed management in direct seeded rice culture: A review, Australian J. Crop Sci. 7, 9891002.

[6] K. W. Abadi (2010). Comparing the effectiveness of some selective herbicides against weeds in bread wheat fields, Iraqi J. Agric. Sci. 41, 150-158.

[7] Y. Ghardea, P. K. Singha, R. P. Dubeya and P. K. Gupta (2018). Assessment of yield and economic losses in agriculture due to weeds in India, Crop Protec. 107, 12-18.

[8] N. Soltani, J. D. Anita, H. G. Robert, L. S. Christy, K. Z. Richard, W. M. Don, C. L. Nevin, M. S. Gustavo, R. K. Andrew, J. Prashant and H. S. Peter (2018). Potential yield loss in dry bean crops due to weeds in the United States and Canada, Weed Tech. 32, 342-346.

[9] M. K. Christopher, B. C. Jed and A. R. Richard (2009). Swamp dodder (Cuscuta gronovii) management in carrot production, Weed Tech. 23, 408-411.

[10] T. Üstüner, S. Kordali, B. A. Usanmaz and M. Kesdek (2018). Investigation of pesticidal activities of essential oil of Eucalyptus camaldulensis Dehnh, Rec. Nat. Prod. 12, 557-568.

[11] N. G. Mushagalusa, B. J. Achiza, B. K. Bisuri, C. B. Sinza, C. L. Bigirimwami and A. K. Lubobo (2016). Cuscuta campestris Yunc, a dangerous obligate parasitic weed observed in cassava crop in the eastern part of the Democratic Republic of Congo, Afr. J. Agric. Res. 11, 1980-1983.

[12] F. Vazin (2012). The effects of pigweed redroot (Amaranthus retoflexus) weed competition and its economic thresholds in corn (Zea mays), Planta Daninha 30, 477-485.

[13] M. A. Xiaoyan, W. U. Hanwen, J. Weili, M. A. Yajie and M. A. Yan (2015). Interference between redroot pigweed (Amaranthus retroflexus L.) and cotton (Gossypium hirsutum L.): Growth analysis, PloSone, 10, $1-18$.

[14] M. Khammassi, H. Chaabane, N. Belbahri and T. Souissi (2018). The impact of Ryegrass density and different herbicides on wheat yield and efficacy of various herbicides against Ryegrass, Turk. J. Weed Sci. 21, 43-52.

[15] A. M. Peerzada, H. H. Ali, Z. Hanif, A. A. Bajwa, L. Kebaso, D. Frimpong, N. Iqbal, H. Namubiru, R. G. Hashim, S. Manalil, A. Meulen and B. S. Chauhan (2017). Eco-biology, impact, and management of Sorghum halepense (L.) Pers., Biol. Invas. 1-19. Doi.10.1007/s,10530-017-1410-8.

[16] G. Erdogan, U. Ahmet and U. Ilhan (2008). Economic impact of Johnsongrass (Sorghum halepense [L.] Pers.) in cotton production in Turkey, J. Plant Dis. Proct. Special Issue XXI, 515-520.

[17] I. A. Said and D. M. A. Jaff (2020). Evaluation of Chevalier WG and Atlantis OD herbicides to control weeds in winter wheat fields, Iraqi J. Agric. Sci. 51, 96-100.

[18] A. M. Sultan (2004). Effect of some herbicides on growth and yield of cotton crop and associated weeds. Iraqi J. Agric. Sci. 5(3), 48-54.

[19] M. M. Hossain and M. Begum (2015). Soil weed seed bank: Importance and management for sustainable crop production- A review, J. Bangladesh Agric. Univ. 13, 221-228.

[20] K. Javed (2020). Allelopathy: A brief review, J. Novel App. Sci. 9, 1-12.

[21] F. T. Al-Chalabi and W. F. Hammood (2016). Response of growth analysis parameters of some cotton cultivars to integrated weed management, Iraqi J. Agric. Sci. 47, 197-207.

[22] S. N. Al-Eqaili, I. S. Alsaadawi and H. M. Aboud (2015). Effect of different rates of sunflower residues in combination with low dose of Chevalier on wheat and companion weeds, Iraqi J. Agric. Sci. 20, $102-$ 111.

[23] N. A. Tahir, K. O. Qader, H. A. Azeez, and J. S. Rashid (2018). Inhibitory allelopathic effects of Moringa oleifera Lamk plant extracts on wheat and Sinapis arvensis L., Allelopathy J. 44, 35-48. 
Almhemed et.al., Rec. Agric. Food. Chem. (2021) 1:1-2 3-11

[24] T. Üstüner (2018). The effect of field dodder (Cuscuta campestris Yunck.) on the leaf and tuber yield of sugar beet (Beta vulgaris L.), Turkish J. Agric. Forest. 42, 348-353.

[25] M. Grašič, S. Anzlovar and S. S. Krajsek (2016). The Impact of aqueous extracts of stinkwort (Dittrichia graveolens) and false yellowhead (D. viscosa) on germination of selected plant species, Phyton; Annal. Rei Botan. 56, 293-301.

[26] S. Anžlovar (2020). Stinkwort (Dittrichia graveolens) organic extracts as potential biofungicides for Fusarium poae, Acta Biol. Slovenica. 63 (2), 19-29.

[27] K. Almhemed, M. AL sakran and T. Ustuner (2020). Effect of seeds age on some treatments efficiency for breaking of dodder (Cuscuta campestris Yunck.) seeds dormancy, Int. J. Sci. and Res. Pub. 10, 326330.

[28] M. AL Sakran, K. Almhemed, T. Ustuner and S. Dal (2021). Effect of aqueous extract of Sorghum halepense (L.) Pers. on germination and growth of some weed species. Int. J. Sci. Res. Pub. 11, 404-408.

[29] ISTA (1999). International rules for seed testing, Seed Sci. Tech. 21, 288.

[30] B. E. Abu Irmaileh, A. M. Al-Aboudi, M. H. Abu Zarga, F. Awwadi and S. F. Haddad (2015). Selective phytotoxic activity of 2,3,11 3,13 - tetrahydroaromaticin and ilicic acid isolated from Inula graveolens, Nat Prod Res. 29, 893-898.

[31] F. Omezzine, A. Ladhari, A. Rinez and R. Haouala (2011). Allelopathic potential of Inula graveolens on crops and weeds, Allelopathy J. 28, 63-76.

[32] A. Guncan (2013). Weeds and control principles, Fifth edition, Selçuk University Press, Konya, Turkey.

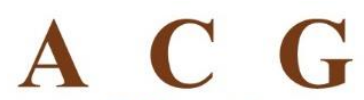

\section{publications}

(C) 2021 ACG Publications 